\title{
EBOLA VIRUS: AN OVERVIEW DISEASE AND TREATMENT
}

\author{
KANAAN AL-TAMEEMI ${ }^{1}$, RAIAAN KABAKLI ${ }^{2 *}$
}

${ }^{1}$ Department of Microbiology, Faculty of Pharmacy, Al-Andalus University for Medical Sciences, Tartous, Syria. ${ }^{2}$ Department of Basic Sciences, Faculty of Pharmacy, Al-Andalus University for Medical Sciences, Tartous, Syria. Email: raiaan82k@yahoo.com

Received: 20 July 2019, Revised and Accepted: 26 August 2019

ABSTRACT

Objective: Ebola virus disease (EVD) is a life-threatening viral disease. Death rate ranges between $30 \%$ and $90 \%$, the first EVD outbreak was reported in the 1970s in Zaire. The global danger of this virus requires the need for producing effective vaccines and drugs is facing its outbreak threat. Even though there is no available commercial vaccine so far against EBOV, a few vaccine candidates are under evaluation to examine their therapeutic efficacy.

Methods: Based on many types of research, we present in our review the properties of the E. virus and EVD, the ongoing efforts to develop diagnostics, vaccines, and drugs for the cure of EVD.

Results: Despite the efforts of health organizations to study, reduce and treat Ebola infection, there are still many challenges including the early diagnosis and control of infection among people in addition to finding a suitable treatment and vaccine in addition to many social and medical reasons.

Conclusion: The good clinical knowledge about the disease and infection control is very important to fight against the outbreaks. Therefore, it is necessary to develop training programs to increase awareness about the diseases in affected areas.

Keywords: Ebola virus, Outbreak, Treatment, Hemorrhagic fever.

(C) 2019 The Authors. Published by Innovare Academic Sciences Pvt Ltd. This is an open access article under the CC BY license (http://creativecommons. org/licenses/by/4. 0/) DOI: http://dx.doi.org/10.22159/ajpcr.2019.v12i10.35005

\section{INTRODUCTION}

EBOV infects primarily humans, monkeys, and bats; but other species such as mice and fawns may also contact infection. There are five identified species of EBOV, four species (Zaire ebolavirus, Sudan ebolavirus, Tai Forest ebolavirus, and Bundibugyo ebolavirus) are known to infect humans and cause disease, whereas Reston ebolavirus is non-human primate pathogen [1-3].

Ebola virus is the causative agent of Ebola hemorrhagic fever (EHF). The first infection was recognized in 1976 in the Northern Democratic Republic of Congo, in Zaire as well. Since then, E. virus disease (EVD) became endemic in Africa. Among these epidemic areas, 318 cases were recorded in DRC, and 284 cases were recorded in Sudan and two different species of EBOV were confirmed: EBOV-Zaire and EBOVSudan. In 1977, one fatal case due to EBOV was reported in Zaire, and EBOV subsequently reemerged with 34 cases, 22 of which were fatal in Sudan in 1979. No further cases were recorded until 1994. In 1995, EVD due to EBOV reemerged in the DRC [3-7].

The chronology of previous EVD outbreaks according to the WHO is shown in Table 1.

\section{Structure of $E$. virus}

E. virus is a filamentous shape virus with dimensions of $800 \mathrm{~nm}$ long and $80 \mathrm{~nm}$ in diameter and has an encapsulated single-stranded negative RNA [9]. There are seven expressed proteins by Ebola:

Nucleoprotein (NP), glycoprotein (GP), RNA-dependent RNA polymerase (L), and four structural viral proteins: (VP24), (VP30), (VP35), and (VP40) (Fig. 1) [10-13].

The role of these proteins is summarized as follows:

- NP: Essential for RNA encapsulation

- GP: Essential for the attachment of the virus to the host cell membrane and entering the nucleocapsid of the virus into the host cytoplasm
- VP24: Essential for virus assembling and in transcription by being a part of the nucleocapsid structure [14]

- VP30: Suppression of viral RNA silencing

- VP35: Binds to NP to remove the nucleocapsid to facilitate the transcriptional expression

- VP40: Required for virus localization out of the host cell membrane and gives filamentous shape to virus together with GP and helps maintain the structural integrity of the virion [15-17].

\section{LIFE CYCLE}

The natural reservoir host of $E$. virus is fruit bats and accidental hosts are humans and non-human primates. E. virus can be directly transferred by blood or body fluids such as urine, saliva, sweat, feces, breast milk, and semen. E. virus also can be transferred by sexual contact [19-23].

After entering the body through small wounds on the skin or mucous membranes, the virus targets monocyte/macrophages and dendritic cells. The infection then spreads through the lymphatic vessels to regional lymph nodes and from there causes secondary viremia infecting the spleen, liver, and adrenal glands (Fig. 2) [13].

Steps of the virus life cycle: Viruses attach to the host receptors by GP which is endocytosed into vesicles in the host cell. Then, the viral membrane fuses with the vesicle membrane, and the nucleocapsid is released into the cytoplasm. The transcription of RNA process begins with the binding of the polymerase complex to a single binding site located within the leader region of the genome. The complex then slides along the RNA template and sequentially transcribes the individual genes in their $3{ }^{\prime}-5$ ' order. Encapsidated, negative-sense genomic ssRNA is used as a template for the synthesis $\left(3^{\prime}-5^{\prime}\right)$ of polyadenylated, monocistronic mRNAs and, using the host cell's ribosomes, tRNA molecules, etc., the mRNA is translated into individual viral proteins, with an increase of viral protein levels, a switch occurs from translation to replication. Assembly starts by the nucleocapsids which accumulate in the perinuclear region; then it is 
Table 1: The chronology of previous EVD outbreaks

\begin{tabular}{|c|c|c|c|c|}
\hline Year & Country & EVD & Cases & Deaths \\
\hline 2018-2019 & $\begin{array}{l}\text { The Democratic } \\
\text { Republic of the } \\
\text { Congo }\end{array}$ & Zaire & Ongoing & \\
\hline 2018 & $\begin{array}{l}\text { The Democratic } \\
\text { Republic of the } \\
\text { Congo }\end{array}$ & Zaire & 54 & 33 \\
\hline 2017 & $\begin{array}{l}\text { The Democratic } \\
\text { Republic of the } \\
\text { Congo }\end{array}$ & Zaire & 8 & 4 \\
\hline 2015 & Italy & Zaire & 1 & 0 \\
\hline 2014 & Spain & Zaire & 1 & 0 \\
\hline 2014 & UK & Zaire & 1 & 0 \\
\hline 2014 & USA & Zaire & 4 & 1 \\
\hline 2014 & Senegal & Zaire & 1 & 0 \\
\hline 2014 & Mali & Zaire & 8 & 6 \\
\hline 2014 & Nigeria & Zaire & 20 & 8 \\
\hline 2014-2016 & Sierra Leone & Zaire & $14124^{*}$ & $3956^{*}$ \\
\hline 2014-2016 & Liberia & Zaire & $10675^{*}$ & $4809^{*}$ \\
\hline 2014-2016 & Guinea & Zaire & $3811^{*}$ & $2543^{*}$ \\
\hline 2014 & $\begin{array}{l}\text { The Democratic } \\
\text { Republic of the } \\
\text { Congo }\end{array}$ & & & \\
\hline 2012 & $\begin{array}{l}\text { Democratic } \\
\text { Republic of Congo }\end{array}$ & Bundibugyo & 57 & 29 \\
\hline 2012 & Uganda & Sudan & 7 & 4 \\
\hline 2012 & Uganda & Sudan & 24 & 17 \\
\hline 2011 & Uganda & Sudan & 1 & 1 \\
\hline 2008 & $\begin{array}{l}\text { Democratic } \\
\text { Republic of Congo }\end{array}$ & Zaire & 32 & 14 \\
\hline 2007 & Uganda & Bundibugyo & 149 & 37 \\
\hline 2007 & $\begin{array}{l}\text { Democratic } \\
\text { Republic of Congo }\end{array}$ & Zaire & 264 & 187 \\
\hline 2005 & Congo & Zaire & 12 & 10 \\
\hline 2004 & Sudan & Sudan & 17 & 7 \\
\hline 2003 & Congo & Zaire & 35 & 29 \\
\hline 2003 & Congo & Zaire & 143 & 128 \\
\hline 2001-2002 & Congo & Zaire & 59 & 44 \\
\hline 2001-2002 & Gabon & Zaire & 65 & 53 \\
\hline 2000 & Uganda & Sudan & 425 & 224 \\
\hline 1996 & South Africa & Zaire & 1 & 1 \\
\hline 1996 & Gabon & Zaire & 60 & 45 \\
\hline 1996 & Gabon & Zaire & 31 & 21 \\
\hline 1995 & $\begin{array}{l}\text { Democratic } \\
\text { Republic of Congo }\end{array}$ & Zaire & 315 & 254 \\
\hline 1994 & Côte d'Ivoire & Taï Forest & 1 & 0 \\
\hline 1994 & Gabon & Zaire & 52 & 31 \\
\hline 1979 & Sudan & Sudan & 34 & 22 \\
\hline 1977 & $\begin{array}{l}\text { Democratic } \\
\text { Republic of Congo }\end{array}$ & Zaire & 1 & 1 \\
\hline 1976 & Sudan & Sudan & 284 & 151 \\
\hline 1976 & $\begin{array}{l}\text { Democratic } \\
\text { Republic of Congo }\end{array}$ & Zaire & 318 & 280 \\
\hline
\end{tabular}

*Including Suspect, Probable and Confirmed EVD cases. Source: World Health Organization [8]. EVD: Ebola virus disease

transported to the budding sites at the plasma membrane. Budding occurs at the plasma membrane where VP40 and GP play important roles in the budding process. Finally, the virion is released [25-28] Fig. 3.

\section{Symptoms of the disease}

The incubation period usually extends 5-7 days, although it can be as minimum as 2 days and as maximum as 21 days.

Approximately $95 \%$ of the patients show signs within 21 days after the infection which is the recommended period for the follow-up of the disease.

Typical symptoms include fever, profound weakness, diarrhea, abdominal pain, cramping, nausea, and vomiting for 3-5 days and

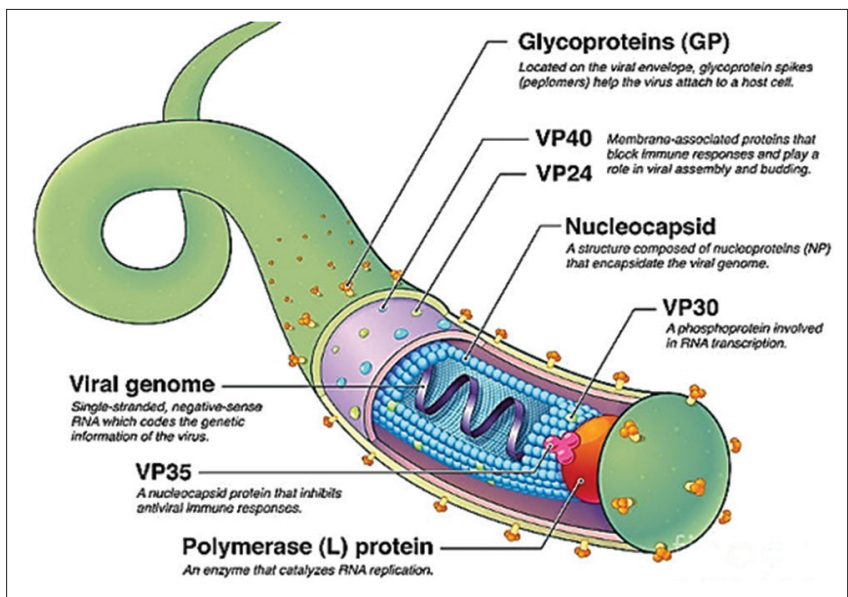

Fig. 1: Structure of Ebola virus [18]

may persist for up to a week. Laboratory complications including elevated aminotransferase levels marked lymphocytopenia, and thrombocytopenia may occur.

Clinical EHF is featured by sudden onset of fever, fatigue, chills, general malaise, headaches, myalgia, anorexia, and gastrointestinal distress within 3-13 days following exposure to the virus [23,30-32]

\section{DIAGNOSIS}

Rapid and reliable diagnosis of EVD is essential for appropriate and effective patient management. Diagnosis of suspected cases is confirmed by EBOV-specific laboratory tests that detect the EBOV genome (e.g., reverse transcriptase polymerase chain reaction [RT-PCR]) [33]. During the period of Ebola infection, viral RNA can be detected by RT-PCR in saliva, tears, sweat, breast milk, urine, vaginal fluid, and seminal fluid regardless of the acute disease [9,12]. Infection can also be diagnosed by measurement of the EBOV antigen or specific antibodies [34], IgM antibodies can be detected starting from 2 days after the first symptoms appear and disappear after 30-168 days. IgG response is generally considered to start between 6 and 18 days post-onset of illness and remains detectable for years [3]. In the past 10 months, the West Africa EVD outbreak has stimulated the development of new diagnostic tests, including rapid antigen detection tests and nucleic acid detection tests such as loop-mediated isothermal amplification assays [34].

\section{INFECTION CONTROL AND TREATMENT}

Immediate isolation of infected cases is very important before proceeding in any action [32]. The risk of E. virus infection can be decreased by averting contact with blood or body fluids from infected people, addition to avoid visiting the patients in the hospital, and by careful hand washing and hygiene [12]. It is necessary to abstain from breastfeeding for the possibility of transmission of the virus through the milk, in addition to safe sex practices, especially after the appearance of infection after the recovery of infected people [19].

So far, there is no authorized safe and effective treatment for EVD. Current treatment is merely supportive, including the control of pain and secondary infections, as well as fluid therapy [35]. Symptoms and complications of EVD should be treated immediately after they occur. Hypovolemia due to massive fluid loss through vomiting and diarrhea is the most common symptom of EVD. Thus, it is necessary to maintain fluid volume by modulation. The electrolyte ratios regulate the daily fluid input and output. It was also observed that antiemetic and antidiarrheal drugs may limit the massive loss of fluids and should be approved [36] when disseminated intravascular coagulation develops. They must control the coagulation factors, the remedy of thrombocytopenia and anemia. In addition, respiratory failure is more often secondary to EVD complications, and therefore, oxygen therapy in severe cases should be used [17,37-39]. 
Table 2: Table of drug clinical trials

\begin{tabular}{|c|c|c|c|}
\hline Product/company & Phase & Trial location & Description \\
\hline Favipiravir Fujifilm/Toyama, Japan & Phase II & $\begin{array}{l}\text { By INSERM in } \\
\text { Guinea: Conakry, } \\
\text { Guéckedou, } \\
\text { Macenta, } \\
\text { Nzérékoré }\end{array}$ & $\begin{array}{l}\text { Used to treat influenza } \\
\text { The drug has been administered to around } 200 \text { patients who } \\
\text { received } 9 \text { days of oral treatment. There is no control group } \\
\text { The EU has announced preliminary findings from these trials } \\
\text { which show the antiviral may be effective in treating patients } \\
\text { with early-stage EVD. In adults and adolescents with a low to } \\
\text { moderate viral load, the case fatality rate was } 15 \% \text { (vs. } 30 \% \text {, } \\
\text { historically). WHO is taking a cautious interpretation given } \\
\text { the lack of concurrent controls in the study }\end{array}$ \\
\hline $\begin{array}{l}\text { TKM-100802 (siRNA) Tekmira, } \\
\text { Canada }\end{array}$ & Phase II & $\begin{array}{l}\text { By Oxford } \\
\text { University in Kerry } \\
\text { Town, Sierra Leone }\end{array}$ & $\begin{array}{l}\text { siRNA - a short RNA sequence that cleaves Ebola RNA in } \\
\text { cells and prevents virus multiplication. Treats } 100 \% \text { of } \\
\text { infected monkeys } \\
\text { A clinical trial started in early March } 2015 \text { in Port Loko, } \\
\text { Sierra Leone, led by Oxford University with funding from the } \\
\text { Wellcome Trust } \\
\text { The trial was halted on June } 19 \text { on the grounds of having met } \\
\text { one of the clinical endpoints. Continuing enrolment was not } \\
\text { likely to demonstrate an overall therapeutic benefit }\end{array}$ \\
\hline ZMapp Mapp USA & Phase II & $\begin{array}{l}\text { By NIAID in Liberia, } \\
\text { Sierra Leone and } \\
\text { the United States of } \\
\text { America }\end{array}$ & $\begin{array}{l}\text { The product has been used on several patients under } \\
\text { compassionate use } \\
\text { A multi-country, the multisite randomized controlled trial } \\
\text { opened to enrollment in Liberia and the United States } \\
\text { in February } 2015 \text { and in Sierra Leone in March } 2015 . \\
\text { Enrollment is ongoing - currently, more than } 35 \text { patients } \\
\text { have been enrolled } \\
\text { No data on efficacy are available yet } \\
\text { Preparations to extend this trial to Guinea (in collaboration } \\
\text { with INSERM) are in progress }\end{array}$ \\
\hline MIL-77 MathWorks, China & Phase I & & $\begin{array}{l}\text { Efficacy in monkeys comparable to Zmapp } \\
\text { To date, used in two expatriated patients under } \\
\text { compassionate use } \\
\text { IND for Phase I filed in China } \\
\text { Prioritized for use on Ebola patients in the condition of not } \\
\text { interfering with the clinical assessment of the efficacy of } \\
\text { Zmapp }\end{array}$ \\
\hline BCX-4430 Biocryst, USA & Phase I & $\begin{array}{l}\text { By Quotient Clinic } \\
\text { in the UK }\end{array}$ & $\begin{array}{l}\text { Broad-spectrum direct-acting nucleoside analog } \\
\text { Phase I safety trial is underway. No efficacy trial is planned } \\
\text { until safety data have been analyzed }\end{array}$ \\
\hline Interferons & Phase II & $\begin{array}{l}\text { By Guinea MOH in } \\
\text { Coyah, Guinea }\end{array}$ & $\begin{array}{l}\text { Approved for the treatment of Hep B and C and multiple } \\
\text { sclerosis }\end{array}$ \\
\hline Amiodarone & Observational & $\begin{array}{l}\text { At the Lakka and } \\
\text { Goderich ETU in } \\
\text { Sierra Leone }\end{array}$ & $\begin{array}{l}\text { Used to treat cardiac dysrhythmia } \\
\text { Was used compassionately in approximately } 80 \text { patients } \\
\text { in Sierra Leone and reportedly reduced case fatality ratio } \\
\text { when compared with local historical norms. The statistical } \\
\text { significance of this result is not known due to variations in } \\
\text { case fatality rates across sites and overtime } \\
\text { This treatment is no longer being used }\end{array}$ \\
\hline $\begin{array}{l}\text { Atorvostatin+Irbesartan } \\
\pm \text { Clomiphene }\end{array}$ & & Sierra Leone & $\begin{array}{l}\text { Approved for cholesterol control/hypertension/infertility, } \\
\text { respectively } \\
\text { Apparently used to treat some patients in Sierra Leone; } \\
\text { however, there has been no confirmation from the treatment } \\
\text { centers that such studies took place, and no clinical data on } \\
\text { the patients are available. Therefore, no conclusion on utility, } \\
\text { safety or efficacy is possible }\end{array}$ \\
\hline Amodiaquine & & $\begin{array}{l}\text { Médecins Sans } \\
\text { Frontiéres (MSF) }\end{array}$ & $\begin{array}{l}\text { Antimalarial products were provided to all patients entering } \\
\text { Ebola treatment centers. When MSF switched from an } \\
\text { antimalarial containing lumefantrine to one containing } \\
\text { amodiaquine, the case fatality rates dropped } \\
\text { It is not known if this is due to the efficacy of amodiaquine } \\
\text { against Ebola or the toxicity of lumefantrine in patients with } \\
\text { EVD }\end{array}$ \\
\hline Brincidofovir Chimerix, USA & Phase II & $\begin{array}{l}\text { By Oxford } \\
\text { University at the } \\
\text { ELWA } 3 \text { Clinic, } \\
\text { Monrovia, Liberia }\end{array}$ & $\begin{array}{l}\text { An antiviral used to treat CMV } \\
\text { Clinical trial halted and abandoned; the drug has been } \\
\text { deprioritized for use in Ebola treatment }\end{array}$ \\
\hline
\end{tabular}

Source: World Health Organization [40] 
Table 3: Table of vaccine clinical trials

\begin{tabular}{|c|c|c|}
\hline Product/company & Phase & Trial location \\
\hline \multirow{4}{*}{ ChAd3-ZEBOV GlaxoSmithKline and PHAC } & Phase I & By VRC at NIH, USA \\
\hline & & By Oxford University in the UK \\
\hline & & By CVD in Mali \\
\hline & & At the University of Lausanne, Lausanne, Switzerland \\
\hline \multirow[t]{7}{*}{ rVSV-ZEBOV NewLink Genetics and Merck Vaccines USA } & Phase I & By WRAIR in the US \\
\hline & & By NIAID in the US \\
\hline & & By CTC North GmbH in Hamburg, Germany \\
\hline & & At Albert Schweitzer Hospital in Lambarene, Gabon \\
\hline & & At the University of Geneva, Geneva, Switzerland \\
\hline & & At the IWK Health Center, Halifax, Canada \\
\hline & & By KEMRI Wellcome Trust in Kilifi, Kenya \\
\hline \multirow[t]{4}{*}{ Ad26-EBOV and MVA-EBOV Johnson and Johnson and Bavarian Nordic } & Phase I & By the University of Oxford in the UK and NIAID, USA \\
\hline & & TBD, Kenya \\
\hline & & TBD, Uganda \\
\hline & & TBD, United Republic of Tanzania \\
\hline Recombinant protein Ebola vaccine candidate Novavax & Phase I & Australia \\
\hline \multirow{5}{*}{ ChAd3-ZEBOV GlaxoSmithKline and PHAC } & Phase II & TBD, Cameroon \\
\hline & & TBD, Ghana \\
\hline & & TBD, Mali \\
\hline & & TBD, Nigeria \\
\hline & & TBD, Senegal \\
\hline VSV-EBOV NewLink Genetics and Merck Vaccines USA & Phase III & $\begin{array}{l}\text { By WHO, Médecins Sans Frontiéres and Government } \\
\text { of Guinea in Conakry, Guinea }\end{array}$ \\
\hline VSV-EBOV & Phase III & $\begin{array}{l}\text { By Médecins Sans Frontiéres, WHO and Government } \\
\text { of Guinea in Conakry, Guinea }\end{array}$ \\
\hline $\begin{array}{l}\text { ChAd3-ZEBOV GlaxoSmithKline and PHACand VSV-EBOV NewLink Genetics } \\
\text { and Merck Vaccines USA }\end{array}$ & Phase II/III & By US NIH and MOH Liberia in Monrovia, Liberia \\
\hline VSV-EBOV NewLink Genetics and Merck Vaccines USA & Phase III & $\begin{array}{l}\text { By US CDC and MOH Sierra Leone in Freetown, Sierra } \\
\text { Leone }\end{array}$ \\
\hline
\end{tabular}

Source: World Health Organization [41]

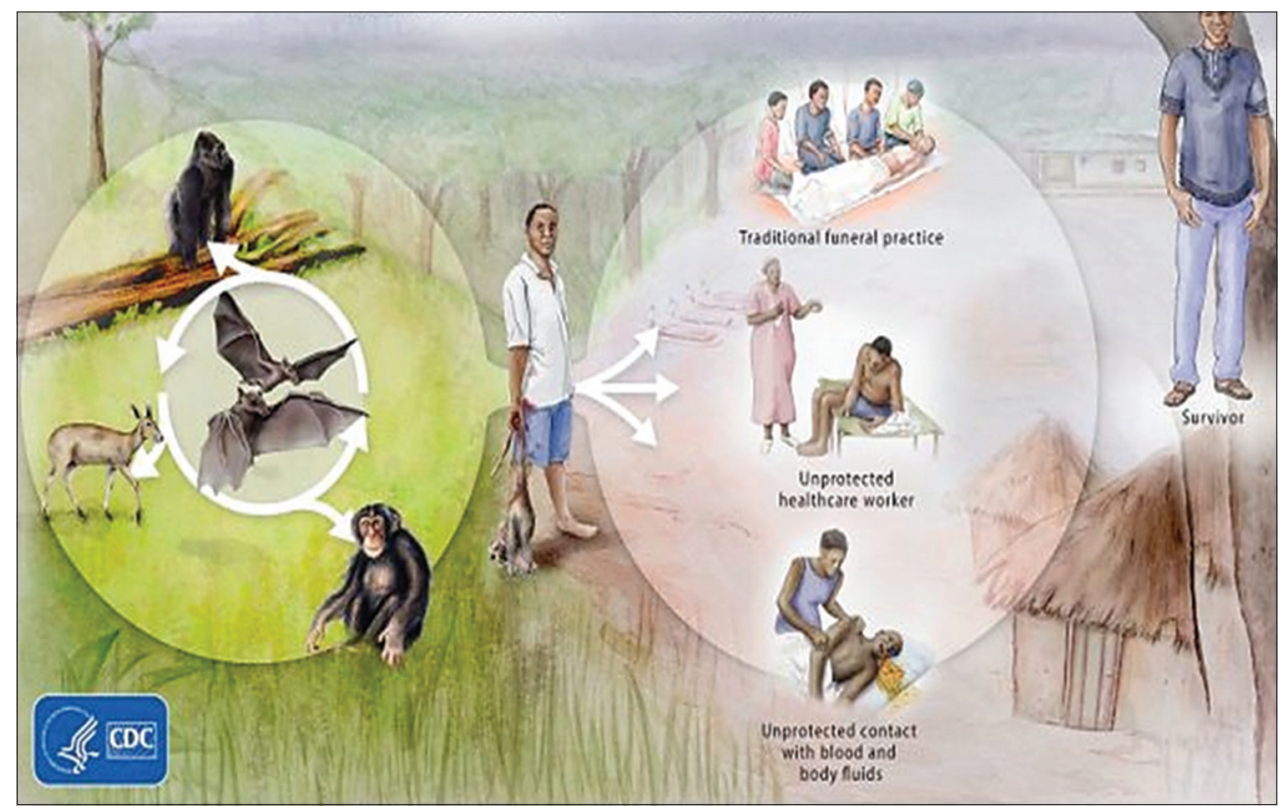

Fig. 2: Ebola virus transmission. Source: Centre for Disease Control [24]

WHO has issued a document for the classification, testing, and use of drugs in patients who are infected with the E. virus, as shown in Table 2 [11].

With the global effect of the West Africa outbreak EVD, research and development for new Ebola vaccine candidates have been stimulated, though no authorized vaccine is currently available. Previously, the development of vaccine candidates has led to the initiation of Phase I, II, and III human clinical trials, Table $3[29,41]$.

\section{CONCLUSION}

The current EVD outbreak urges the health care and public health systems to respond to infectious disease emergencies and develop the healthcare infrastructure in developing countries and to increase awareness in countries at risk for EVD imported cases [3,7]. Human Ebola outbreaks usually occur unexpectedly with a subsequent rapid spread from person to person. E. viruses are highly contagious infectious. Understanding the clinical aspects, immediate diagnosis and suitable treatment are major steps toward the prevention of death and transmission of the virus to other people [9] 


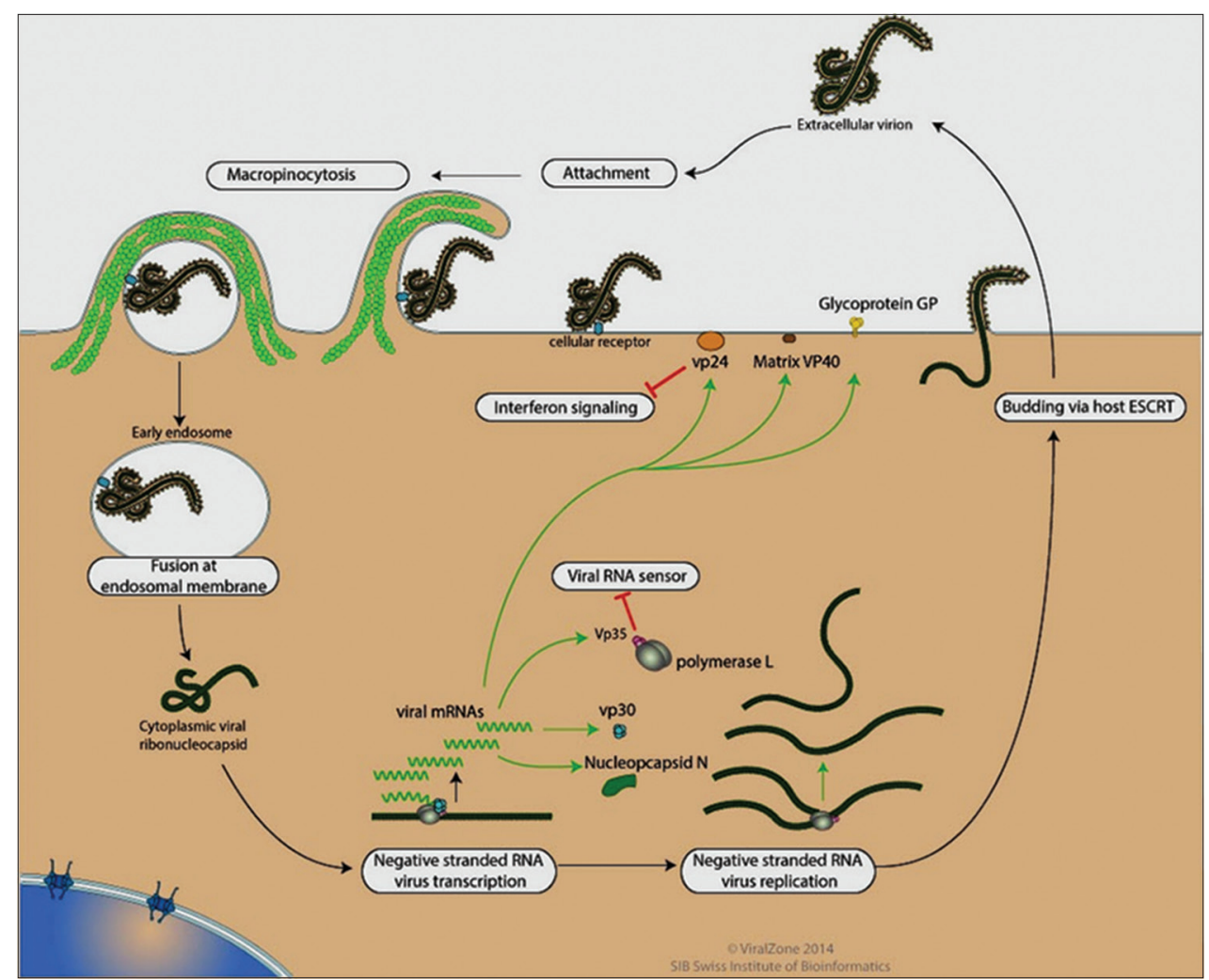

Fig. 3: The life cycle of Ebola, Source: ViralZone, Swiss Institute of Bioinformatics [29]

\section{AUTHORS' CONTRIBUTIONS}

Both authors have contributed for review article preparation and editing of the manuscript.

\section{CONFLICTS OF INTEREST}

We declare that there are no conflicts of interest.

\section{REFERENCES}

1. Dhama K, Karthik K, Khandia R, Chakraborty S, Munjal A, Latheef SK, et al. Advances in designing and developing vaccines, drugs, and therapies to counter Ebola virus. Front Immunol 2018;9:1803.

2. Kourtis AP, Appelgren K, Chevalier MS, McElroy A. Ebola virus disease: Focus on children. Pediatr Infect Dis J 2015;34:893-7.

3. Goeijenbier M, van Kampen JJ, Reusken CB, Koopmans MP, van Gorp EC. Ebola virus disease: A review on epidemiology, symptoms, treatment and pathogenesis. Neth J Med 2014;72:442-8

4. Kimura H, Tsukagoshi H, Ryo A, Oda Y, Kawabata T, Majima T, et al. Ebola virus disease: A literature review. J Coast Life Med 2015;3:85-90.

5. World Health Organization. High-level Meeting on the Ebola Outbreak in the Democratic Republic of the Congo Affirms Support for Government-led Response and UN System-wide Approach; 2019.

6. Jean-Jacques Muyembe Tamfum: A life's work on ebola. Bull World Health Organ 2018;96:804-5.

7. Kaner J, Schaack S. Understanding ebola: The 2014 epidemic. Globalization and Health 2016;12:53.

8. World Health Organization, Ebola virus Disease; 2019. Available from: https://www.who.int/news-room/fact-sheets/detail/ebola-virus-disease.

9. Malvy D, McElroy AK, de Clerck H, Günther S, van Griensven J. Ebola virus disease. Lancet 2019;393:936-48.

10. Majid MU, Tahir MS, Ali Q, Rao AQ, Rashid B, Ali A, et al. Nature and history of Ebola virus: An overview. Arch Neurosci 2016;3:e35027.

11. Yobsan D, Walkite F, Nesradin Y. Ebola virus and its public health significance: A review. J Vet Sci Res 2018;3:165.

12. Abouelwafa M, George JJ. Ebola virus and its Potential Drug Targets, International Science Symposium on Recent Trends in Science and Technology February 26 and 27; 2017.

13. Kumar S, Kumari R, Pandey R, Sharma V. Ebola virus disease: Biology, diagnosis, treatment and prevention of epidemics. Proc Indian Natl Sci Acad 2017;83:103-49.

14. Parasuraman P, Suresh RS, Perumal P. Searching antiviral drugs for Ebola virus from phytoconstituents of Azadirachta indica: Application of molecular modelling studies. Asian J Pharm Clin Res 2017;10:254-7.

15. Madariaga MG. Ebola virus disease: A perspective for the United States. Am J Med 2015;128:682-91.

16. Cantoni D, Rossman JS. Ebolaviruses: New roles for old proteins. PLoS Negl Trop Dis 2018;12:e006349.

17. Munjita SM, Kwenda G. Descriptive analysis of bola virus proteins: Towards development of effective therapeuticsand vaccines. $\mathrm{Br}$ Microbiol Res J 2015;8:457-79.

18. Avaliable from: https://www.fineartamerica.com/featured/ebola-virusillustration-evan-oto.html?product=art-print.

19. Centers for Disease Control and Prevention, Ebola virus Disease EVD; 2018. Available from: http://www.cdc.gov/vhf/ebola.

20. Ruparelia C, Curless M, Trexler P, Black M. Prevention and Control of Ebola Virus Disease in Health Care Facilities with Limited Resources, Reference Manual; 2015.

21. Fischer WA, Brown J, Wohl DA, Loftis AJ, Tozay S, Reeves E, et al. Ebola virus ribonucleic acid detection in semen more than two years after resolution of acute Ebola virus infection. Open Forum Infect Dis 2017;4:ofx155.

22. Boon SD, Marston BJ, Nyenswah TG, Jambai A, Barry M, Keita S, et al. Ebola virus infection associated with transmission from survivors. Emerg Infect Dis J 2019;25:2019.

23. Mustafa M, Yusof MI, Kassim M, Jeffree MS, Illzam EM, Sharifa AM. Ebola virus disease, management, and prevention. IOSR J Dent Med Sci 2016;15:142-8

24. Available from: https://www.cdc.gov/vhf/ebola/resources/virus-ecology. html.

25. Yu DS, Weng TH, Wu XX, Wang FXC, Lu XY, Wu HB, et al. The lifecycle of the Ebola virus in host cells. Oncotarget 2017;8:55750-9.

26. Madelain V, Nguyen TH, Olivo A, de Lamballerie X, Guedj J, Taburet AM, et al. Ebola virus infection: Review of the pharmacokinetic and pharmacodynamic properties of drugs considered for testing in human efficacy trials. Clin Pharmacokinet 2016;55:907-23.

27. Salata C, Calistri A, Alvisi G, Celestino M, Parolin C, Palù G, et al. Ebola virus entry: From molecular characterization to drug discovery. Viruses 2019;11:E274. 
28. Available from: https://www.viralzone.expasy.org/5016.

29. Kaushal S, Kumari S. A review on Ebola virus, the diseases, causes and management. Int Res J Pharm 2017;8:1-8.

30. Khalafallah MT, Aboshady OA, Moawed SA, Ramadan MS. Ebola virus disease: Essential clinical knowledge. Avicenna J Med 2017;7:96-102.

31. Moghadam SR, Omidi N, Bayrami S, Moghadam SJ, Seyedalinaghi S. Ebola viral disease: Review literature. Asian Pac J Trop Biomed 2015;5:260-7.

32. Broadhurst MJ, Brooks TJ, Pollock NR. Diagnosis of Ebola virus disease: Past, present, and future. Clin Microbiol Rev 2016;29:773-93.

33. Martínez MJ, Salim AM, Hurtado JC, Kilgore PE. Ebola virus infection: Overview and update on prevention and treatment. Infect Dis Ther 2015;4:365-90.

34. Chertow DS, Kleine C, Edwards JK, Scaini R, Giuliani R, Sprecher A, et al. Ebola virus disease in West Africa clinical manifestations and management. N Engl J Med 2014;371:2054-7.

35. West TE, von Saint André-von Arnim A. Clinical presentation and management of severe Ebola virus disease. Ann Am Thorac Soc
2014;11:1341-50.

36. Francesconi P, Yoti Z, Declich S, Onek PA, Fabiani M, Olango J, et al. Ebola hemorrhagic fever transmission and risk factors of contacts, Uganda. Emerg Infect Dis 2003;9:1430-7.

37. Dyary HO, Rahman HS, Othman HH, Abdullah R, Chartrand MS. Advancements in the therapy of Ebola virus disease. Pediatr Infect Dis 2016;1:22.

38. Joffe S. Evaluating novel therapies during the ebola epidemic. JAMA 2014;312:1299-300

39. World Health Organization. Essential Medicines and Health Products; 2019. Available from: https://www.who.int/medicines/ebola-treatment/ ebola_drug_clinicaltrials/en.

40. Espeland EM, Tsai CW, Larsen J, Disbrow GL. Safeguarding against ebola: Vaccines and therapeutics to be stockpiled for future outbreaks. PLoS Negl Trop Dis 2018;12:e0006275.

41. World Health Organization. Essential Medicines and Health Products; 2019. Available from: https://www.who.int/medicines/ebola-treatment/ ebola_vaccine_clinicaltrials/en. 